TITLE:

\title{
Environmental assessment and accounting for the waste disposal stream in Bangkok, Thailand
}

$\operatorname{AUTHOR}(S)$ :

Inazumi, Shinya; Ohtsu, Hiroyasu; Shiotani, Tomoki; Katsumi, Takeshi

\section{CITATION:}

Inazumi, Shinya ... [et al]. Environmental assessment and accounting for the waste disposal stream in Bangkok, Thailand. Journal of Material Cycles and Waste Management 2011, 13(2): 139-149

ISSUE DATE:

2011-08

URL:

http://hdl.handle.net/2433/145956

\section{RIGHT:}

The final publication is available at www.springerlink.com; This is not the published version. Please cite only the published version.; この論文 は出版社版でありません。引用の際には出版社版をご確認ご利用くだ さい。 
[ Original articles ]

\title{
Environmental Assessment and Accounting for Waste Disposal Stream in Bangkok, Thailand
}

\author{
Shinya Inazumi ${ }^{1 *}$, Hiroyasu Ohtsu ${ }^{2}$, Tomoki Shiotani ${ }^{3}$ and Takeshi Katsumi ${ }^{4}$
}

\begin{abstract}
:
It is very important that waste should be controlled and appropriately handled in a waste disposal stream in consideration of its impact on the environment. In this research, the LCA-EA model is applied to the current waste disposal stream of the BMR as well as other waste disposal streams assumed as scenarios, so that treatment cost, environmental load and environmental cost are assessed quantatively. As a result of this study, it showed that in the current waste diposal stream in Bangkok, the carbon dioxide and methane gases contribution to greenhouse was large. The study was able to provide the reduction effect of environmental load quantitatively in the countermeasure scenarios using the baseline scenario as a standard.
\end{abstract}

\footnotetext{
${ }^{1}$ Assistant Professor, Graduate School of Engineering, Kyoto University

${ }^{2}$ Professor, Graduate School of Engineering, Kyoto University

${ }^{3}$ Associate Professor, Graduate School of Management, Kyoto University

${ }^{4}$ Professor, Graduate School of Global Environmental Studies, Kyoto University

* Corresponding author
} 


\section{Introduction}

In many developing countries, various environmental problems such as air pollution or water contamination due to delays in social capital improvement have grown into serious problems, and policy issues related to national land have become obvious. In this research, Thailand was selected among developing countries, and attention was focused on waste disposal stream in the BMR (Bangkok Metropolitan Region) and the various environmental problems associated with waste disposal, which is closely related to natural environment. The BMR is referred to as a general area that includes the capital Bangkok as well as five prefectures around the BMA (Bangkok Metropolitan Area): Samut Prakan, Pathum Thani, Samut Sakhon, Nakhon Pathom and Nonhaburi.

Currently, in many developing countries, waste collected in each area directly goes to landfill without treatment. This is the most common stream of waste disposal. When waste containing large amounts of organic substances goes to landfill in this stream, the environment of the landfill site will worsen due to sewage and foul odors, while greenhouse effect gases including methane gas $\left(\mathrm{CH}_{4}\right)$ will be generated due to anaerobic decomposition. Therefore, the waste disposal stream that is most commonly used in many developing countries becomes one of the causes of global warming or spontaneous fires. In addition to this, it brings about environmental degradation at the landfill sites. Because untreated waste has a large volume, landfill sites become full quickly if the waste is directly dumped. This means new landfill sites must be prepared continuously. However, it is not easy even in developing countries to prepare new landfill sites because of opposition of residents in the vicinity. As a result, the issue regarding lack of land space for landfill sites has been brought up. ${ }^{1}$ The socially vulnerable suffer from the problems of environmental degradation mentioned above. Especially in densely inhabited urban areas of developing countries such as 
the BMR, a great volume of waste is generated and many socially vulnerable people suffer from waste disposal processes. Therefore, it is necessary to immediately start studying comprehensive waste disposal with the environment taken into consideration.

This research focuses on waste disposal in the BMR of Thailand. Specifically, environment assessment as well as environment accounting is applied to the waste disposal stream currently used there and a model waste disposal stream assumed as a scenario, so that treatment cost (disposal cost) associated with the mentioned streams as well as environment loads and environment costs are evaluated quantitatively. Furthermore, we discuss waste disposal streams that can comprehensively optimize (minimize) treatment costs (disposal costs) and environment costs in the BMR.

\section{Current conditions of waste disposal, environmental assessment and accounting}

\section{Current conditions of waste disposal in Thailand}

Because environmental problems worsened owing to rapid industrialization and urbanization in Thailand, the "National Environment Conservation Law" was established in 1975. However, the law did not work sufficiently and was abolished in 1992. In that year "Law of National Environment Conservation Promotion" was newly established. At present, environmental rules are stipulated under the "Law of National Environment Quality Improvement \& Conservation" which is equivalent to our Basic Environment Law. ${ }^{2}$

In Thailand waste is classified into five categories: general solid waste, infectious waste, harmful industrial waste, non-harmful industrial waste and harmful general waste. ${ }^{3}$ General solid waste accounts for $67 \%$ of all waste and approximately $30 \%$ of it comes from the BMR. Furthermore, kitchen waste (garbage) has the largest proportion of general solid 
waste and it is made up mostly of organic waste (see Table 3 to be mentioned later). ${ }^{3}$

General solid waste of the BMR is collected from exclusive places located by administrative organizations, or houses or facilities. It is sent to landfill sites by way of solid waste transfer stations or temporary landfill sites. In order to avoid traffic jams, collection of waste is done in the evening or later. The collection ratio is almost $100 \%$, better than those of other developing countries. ${ }^{2,4}$ Nevertheless, the collection efficiency is not so good because the area has many small streets and collection operators have their own recycling method. In addition, valuable goods in the waste placed at solid waste transfer stations or temporary landfill sites are picked up by waste pickers and sold in unofficial used goods stores. ${ }^{1}$ Intermediate treatment of waste is not performed at the solid waste transfer stations or temporary landfill sites. When waste is brought to landfill sites, it is simply covered with soil. In the BMR, only a small amount of money is collected from residents for waste disposal. Thus, the operational cost required for waste disposal is not sufficiently covered. ${ }^{5}$

Figure 1 shows records of waste volumes generated in the entire Thailand and the BMR. The figure also carries data for population and GDP of Thailand. Based on the data in Fig. 1, "The Ninth National Economic \& Social Development Plan (2002)" gave priority to recycling business with the targets of suppression of waste production, recycling of waste, and thorough control of waste (see Table 1$).^{5}$

\section{Life cycle assessment and environmental accounting}

In order to predict, evaluate and reduce environment loads related to a waste disposal stream, LCA (Life Cycle Assessment) is required to be done. By use of LCA related to a waste disposal stream, it is possible to quantify roughly various substances with environmental load (e.g. air pollutants, water contaminants and waste itself) that are released during the disposal process from waste collection to final disposal via intermediate treatment. ${ }^{6}$ 
Furthermore, by use of EA (Environmental Accounting), various environmental impacts qualified by LCA can be expressed by the basic unit of money value, so that environmental impact can be dealt with as environment cost. ${ }^{6,7}$ This way, although treatment cost related to a waste disposal stream is different in dimension from environmental loads, they can be dealt with by the common index (monetary unit) by effective combination of LCA and EA. Eventually, they can help us make a proposal regarding the optimal waste disposal stream in terms of environmental economics.

It has been attempted by many to create environment assessment models of a waste disposal stream by use of LCA or equivalents. For example, in the 1970s, Clark (1978) ${ }^{8}$ reviewed a modeling method to optimize a waste collection method, predict the shortest route of collection and locate the optimal landfill sites. These models were based on detailed analysis of each process. On the other hand, Greenberg et al. (1976) ${ }^{9}$ compared an alternative of waste disposal from the viewpoint of economics. Among the researches in the 1990s, a detailed modeling of the economics of material recycling and its environmental loads (Boustead, 1992) $)^{10}$ and a wider modeling of the cost of alternatives of waste disposal including acceptability of residents, environmental loads and easiness of operation and maintenance (Sushil, 1990) ${ }^{11}$ are typical. In addition to those, models to estimate $\mathrm{CO}_{2}$ emission, energy consumption and disposition cost based on material flow in the waste disposal stream by O.H. Giljomg et al. (1996) ${ }^{12}$ and recently by T. Matsuto (2005) ${ }^{13}$.

As described later, the model used in this research is a model of LCA and EA (hereafter it is referred as LCA-EA model) and based on the LCA model proposed by O.H. Giljomg et al. (1996) $)^{12}$ and T. Matsuto $(2005)^{13}$ with EA being introduced. 


\section{LCA-EA model of waste disposal stream for the BMR: setup and review}

\section{Overview of LCA-EA model}

It is necessary to select a disposal stream in which as much as possible of the environmental load is reduced when trying to dispose of waste. However, for the cost to operate the waste disposal stream, taxes collected from residents are used in many cases. It means that even a waste disposal stream in which environmental load is reduced as low as possible cannot be practical if a huge treatment cost is required. Generally, a waste disposal stream with "small environmental load" and "small treatment cost" is ideal, but because they exist in different 'dimensions', they cannot be compared with each other easily. Therefore, when a waste disposal stream is to be evaluated, it is considered necessary that both should be compared at the same dimension by converting environment load into monetary value the same as treatment cost. This way, the validity of the cost used for reduction of environmental load can be reviewed.

The LCA-EA model used in this research is a model that can deal with environmental impact and treatment cost at the same time. It evaluates environmental load and treatment cost quantitatively and in due course a waste disposal stream to optimize both environmental cost and treatment cost in a comprehensive way can be developed. In this model, the greenhouse emission burden in the process of waste deposal and final disposal volume of waste are focused on as environmental load. Furthermore, greenhouse effect gases consist of carbon dioxide $\left(\mathrm{CO}_{2}\right)$, methane gas $\left(\mathrm{CH}_{4}\right)$ and dinitrogen monoxide $\left(\mathrm{N}_{2} \mathrm{O}\right)$.

\section{Emission factor, emission basic unit and monetary value basic unit in LCA-EA model}

\section{Emission factor and emission basic unit:}

Because this research focuses on Thailand, the emission factors (defaults) in the 
IPCC guidelines ${ }^{14}$ and emission basic units estimated by the inter-industry relations analysis from literature ${ }^{15}$ in Thailand are referenced and used for emission factors and emission basic units of $\mathrm{CO}_{2} \mathrm{CH}_{4}$, and $\mathrm{N}_{2} \mathrm{O}$ related to energy materials, materials, products and civil engineering/construction work (see Table 4 to be mentioned later). Note that the absolute values of emission of $\mathrm{CO}_{2} \mathrm{CH}_{4}$, and $\mathrm{N}_{2} \mathrm{O}$ estimated by using the emission basic units may have some problems regarding accuracy, but it is considered they can be used for comparison of emissions.

$\underline{\text { Monetary value basic unit: }}$

Regarding the conversion of the emission of substances with environmental load, especially $\mathrm{CO}_{2}$, into monetary value, the concept of measuring the monetary value basic unit is described in a document by the Ministry of Land, Infrastructure and Transport, "Technical Guideline about Cost Benefit Analysis for Public Work Assessment" (2004). ${ }^{16}$ The concept of measurement has the following three aspects:

(1) Measurement based on damage cost,

(2) Measurement based on countermeasure cost, and

(3) Measurement based on emission trading price.

Among the three, (1) Measurement based on damage cost, is not easily influenced by policy trends and stability against external factors. Besides, it can allow for international fairness. (1) Measurement based on damage cost is also referred to in a distinguished report analyzing the economic impact of climate changes. ${ }^{17}$ This report ${ }^{17}$ summarizes marginal damage cost of $\mathrm{CO}_{2}$ emissions based on 103 examples of measurement and it is considered as one of the most reliable reports at present. More specifically, regarding $\mathrm{CO}_{2}$ emissions marginal damage cost (conversion of damage into monetary value; for example, monetary expression of sea level rise when a unit of $\mathrm{CO}_{2}$ emission increases), it collected 103 measurement examples and calculated the average and variance of the measurements; the 
average of all the measurements was $3.3 \mathrm{yen} / \mathrm{kg}-\mathrm{CO}_{2}$.

Following the trend described above, this research has adopted (1) Measurement based on damage cost to define the monetary value basic unit of $\mathrm{CO}_{2}$ and used $3.03 \mathrm{yen} / \mathrm{kg}$ $\mathrm{CO}_{2}$ as described in the report. ${ }^{17}$ In addition, as for defining the monetary value basic units of $\mathrm{CH}_{4}$ and $\mathrm{N}_{2} \mathrm{O}$, the fact that their factors of warming effect are 21 and 310, respectively, is considered, and they were decided to be 63.63 yen $/ \mathrm{kg}-\mathrm{CH}_{4}$ and $939.3 \mathrm{yen} / \mathrm{kg}-\mathrm{N}_{2} \mathrm{O}$, respectively.

On the other hand, in case waste was discarded illegally, soil was found to be polluted, or waste was directly buried (anaerobic landfill), some measures need to be taken in order to reuse the land. For the cost of the measures, this research defines the monetary value basic unit. Explicitly, the monetary value basic unit of anaerobic landfill is determined to be $1,000 \mathrm{yen} / \mathrm{m}^{3}$ with the difference in prices of commodities between the BMR and Japan (1 baht $=3$ yen) taken into consideration. The monetary value basic unit was determined based on the monetary value basic unit in the report $\left(3,000 \mathrm{yen} / \mathrm{m}^{3}\right)^{18}$. As for sanitary landfill without cover soil and sanitary landfill with cover soil, assuming that final disposal is properly controlled, no monetary value basic unit is defined for final disposal.

\section{Waste disposal in the BMR (information for input)}

Tables 2 and 3 show the waste volumes generated in the BMR and composition (\%) that were used as information to be inputted into the LCA-EA model. ${ }^{3,19}$

Most of the waste is collected every day in the BMR. As shown in Fig. 2, they are brought into the three solid waste transfer stations in each area (OnNut, Nogkhaem and Tharaeng) for control. In the solid waste transfer stations the waste is packed into containers without intermediate treatment and the containers are transported to the landfill sites (Phanomsarakam and Kamphaengsaen) for disposal as predetermined for each facility. ${ }^{3}$ 
However, the waste is simply covered with soil at the disposal sites; so the sites are considered as anaerobic landfill sites. ${ }^{20}$ In summary, the waste collected from the BMR is simply disposed at the anaerobic landfill sites in the suburbs; it is difficult to designate this way of simple disposal as properly controlled disposal.

\section{Assumed waste disposal process and disposal stream}

Figure 3 shows various waste disposal processes that are used when the LCA-EA model is applied to the waste disposal stream for the BMR. Note that the treatment cost, environmental load and environmental cost of the total waste disposal stream can be obtained by adding up the treatment cost, environmental load and environmental cost estimated for each step.

\section{Collection process:}

The flow from collecting waste at each point in the district to carrying it to a solid waste transfer station is dealt with. The average distance from each point to the solid waste transfer station is shown in Table 2 .

\section{Intermediate treatment process:}

For an intermediate treatment process, the flow of treatment at an intermediate treatment facility is studied. The treatment includes weight reduction, volume reduction and the stabilization process for collected waste. For this process, the following facilities are considered: resource sorting facilities, composting facilities and incineration treatment facilities.

\section{$\underline{\text { Transportation process: }}$}

For the transportation process, the flow of transportation of residue after an intermediate treatment is reviewed; it is carried from the solid waste transfer station to the landfill site (the average distance is shown in Table 2.). Because the residue volume varies 
depending on the selected intermediate treatment, estimation is done in coordination with the intermediate treatment process.

Final disposal process:

For final disposal process, the flow of final processes to dispose of the waste carried into the landfill site without harming nature, including living creatures, is reviewed. This research deals mainly with the final disposal methods below: open dumping, sanitary landfill without cover soil and sanitary landfill with cover soil. The volume of wastes to be carried into the landfill site is considered as final disposal volume.

Table 4 shows emission factors and emission basic units of $\mathrm{CO}_{2}, \mathrm{CH}_{4}$, and $\mathrm{N}_{2} \mathrm{O}$ used in this research. ${ }^{12,13,14,15}$ For determining the basic unit of each price including selling price, difference in prices between the BMR and Japan ( 1 baht $=3$ yen $)$ is considered. In addition, various values described in the literatures ${ }^{12,13}$ are quoted and converted while focusing on the BMR (see Table 5). Note that various values other than basic unit that were required for establishing the LCA-EA model were so enormous that their description was omitted. However, for those values, the recommended values based on the on-site surveys as described in the literatures ${ }^{12,13}$ as well as on interviews with responsible persons at those facilities are used.

\section{$\underline{\text { Setup of scenarios: }}$}

In this research, several scenarios of waste disposal stream for the BMR were set up while combining the intermediate treatment processes with the final disposal processes. The treatment cost, environmental load and environmental cost of each scenario are evaluated by using the LCA-EA model. Table 6 shows all the scenarios. There are 18 combinations in total. Note that the combination of "no treatment" for intermediate treatment process and "anaerobic landfill disposal" is most representative for the waste disposal stream in the BMR. So, the scenario No. 1 in Table 6 is considered as the baseline scenario. The other scenarios 
except No. 1 are designated as proposed scenarios.

Life cycle assessment and environmental accounting of the waste disposal stream in the BMR

\section{Assessment based on the scenario setups}

\section{Treatment cost:}

Figure 4 shows the treatment cost of each scenario. The treatment cost of the baseline scenario in the table has a breakdown below: approximately $53 \%$ for collection process, $37 \%$ for the transportation process and $10 \%$ for the final disposal process. It means that the current waste disposal stream in the BMR spends a large proportion of the cost on collection of waste. Then, because the treatment cost for the collection process can be reduced by improving waste collection efficiency, it is thought that the collection work efficiency should be incorporated into LCA-EA models as a parameter.

The proposed scenarios with composting facilities and incineration disposal facilities selected for the intermediate treatment process (scenarios 3 to 6,9 to 12 and 15 to 18 ) had higher treatment costs as a whole compared with that of other proposed scenarios (see Fig. 4). This is because those facilities have high construction costs. However, though the figures used for construction costs of an intermediate treatment facility in this research are adjusted with the difference in prices between the BMR and Japan ( 1 baht $=3$ yen $)$, the original figures are based on the hearing investigation performed for similar facilities in Japan. Therefore, the construction costs may be notably different if an intermediate treatment facility is to be actually built in the BMR. Note that construction cost of an intermediate treatment facility in a developing country can be reduced by either selecting appropriate construction technologies 
from abroad or by economic support from other countries. Then, it is necessary to consider in the LCA-EA models what construction technologies are to be introduced or whether financing help from other countries is available or not.

\section{Greenhouse effect gas emission:}

Figure 5 shows greenhouse effect gas emissions of each scenario. The greenhouse effect gas means here a sum total of emissions of $\mathrm{CO}_{2}, \mathrm{CH}_{4}$ and $\mathrm{N}_{2} \mathrm{O}$ in each scenario; it is expressed by $\mathrm{CO}_{2}$ emissions through conversion. Conversion of $\mathrm{CH}_{4}$ and $\mathrm{N}_{2} \mathrm{O}$ emissions into $\mathrm{CO}_{2}$ emission is done by using their warming factors, 21 and 310 , respectively. Figure 5 indicates the baseline scenario releases much more greenhouse effect gas than proposed scenarios. When only $\mathrm{CO}_{2}$ emission is considered, the proposed scenarios with incineration disposal facilities selected (scenarios 4, 6, 10, 12, 16 and 18) have a high degree of $\mathrm{CO}_{2}$ emissions; however, when greenhouse effect gas emissions is considered, the baseline scenario has more than others. This is because $\mathrm{N}_{2} \mathrm{O}$ emission (converted into $\mathrm{CO}_{2}$ emission) of the baseline scenario is more than the $\mathrm{CO}_{2}$ emissions of proposed scenarios; for example, the scenarios with incineration disposal facilities selected. Therefore, when each scenario is evaluated from the viewpoint of how it affects global warming, the current waste disposal stream of the BMR (i.e. baseline scenario) affects it remarkably, while proposed scenarios with any treatment/disposal adopted can comparatively mitigate the greenhouse effect.

Note that for the baseline scenario approximate 3 million tons of greenhouse effect gas is released in a year (see Fig. 5). Assuming that the population of the BMR is 6 million, one person releases approximate $500 \mathrm{~kg} / \mathrm{year}$ of greenhouse effect gas. In contrast, one person in Japan releases approximate $77 \mathrm{~kg} /$ year of greenhouse effect gas when estimated based on the literature about the greenhouse effect gas emission associated with general waste treatment (in 2007). ${ }^{21}$ In summary, it is assumed that the waste disposal stream of the BMR is less environmentally efficient than that of Japan. 
Final disposal volume:

Figure 6 shows the final disposal volume of wastes for each scenario. The final disposal volume of proposed scenarios varies depending on what is selected for the intermediate treatment. The proposed scenarios with incineration disposal facilities selected as intermediate process (scenarios 4, 6, 10, 12, 16 and 18) have a remarkably large reduction of wastes; so if they are compared with the baseline scenario, the final disposal volume is smaller by $87 \%$. The proposed scenarios with other intermediate treatment processes selected also have smaller final disposal volume than that of the baseline scenario.

Environmental load:

Environmental load is defined as an integration of greenhouse effect gas emissions and the final disposal volume of waste. Figure 7 shows the greenhouse effect gas emissions and final disposal volume of waste of each scenario. Thus, environmental load is expressed by the distance from the origin of the coordinate to each plot in Fig. 7. This way, if any proposed scenario is selected, environmental load will be reduced compared with the baseline scenario. Especially, the proposed scenarios with composting facilities or incineration disposal facilities selected as an intermediate process demonstrate a remarkable decrease of both greenhouse effect gas and final disposal volume. Also, the proposed scenarios with composting facilities or incineration disposal facilities selected have smaller variance among them even when the final disposal process is different. This is because it is assumed that the residue after incineration does not release $\mathrm{CH}_{4}$.

\section{Evaluation based on environmental cost}

$\underline{\text { Evaluation based on total cost: }}$

The total cost of each scenario is defined as to be the sum total of the treatment cost and environmental cost which is the result of the conversion of environmental load into 
monetary value. Figure 8 shows the total cost of each scenario. In this way, all the proposed scenarios except those with compost facilities for the intermediate treatment process and open dumping for the final disposal process (scenarios 3 and 5) can reduce the total cost more than the baseline scenario. If scenarios are evaluated only by treatment cost, the baseline scenario's cost is the cheapest as shown in Fig. 4. On the contrary, if scenarios are evaluated by total cost, which is the sum total of treatment cost and environmental cost, selection of a proposed scenario will be effective in reducing the total cost. Therefore, it is true that the introduction of a proposed scenario means a cost increase because of an intermediate treatment process and final disposal process of the waste disposal stream, but it can reduce environmental cost. In other words, because environmental cost occupies a large proportion of total cost, introduction of a proposed scenario is effective for the reduction of the total cost.

\section{Evaluation based on environmental efficiency:}

Generally speaking, environmental efficiency is expressed social benefit and environmental load. It reflects the concept of maximizing the social benefit while minimizing environmental load. Note that though unified standard for environmental efficiency has not been established, the concept of environmental efficiency is drawing attention because it can be used as one of the indexes for assessment of corporate activities. ${ }^{22}$

In this research, social benefit is defined as the difference in total cost between a proposed scenario and the baseline scenario, and environmental load is defined as the environmental cost of a proposed scenario. Thus, environmental efficiency of a proposed scenario against the baseline scenario is obtained. Figure 9 shows the environmental efficiency of each proposed scenario against the baseline scenario. It confirms that the introduction of a proposed scenario into the waste disposal stream for the BMR has a preferable environmental efficiency against the baseline scenario. Especially, the scenarios with sanitary landfill without cover soil selected for the final disposal process (scenarios 7 to 
12) have higher environmental efficiency. In addition, the scenario with a resource sorting facility selected for the intermediate treatment process (scenario 8) has the highest environmental efficiency among all the assumed proposed scenarios. It implies that proposed scenarios with a resource sorting facility selected for the intermediate treatment process and sanitary landfill without cover soil disposal selected for the final disposal process are wellbalanced in terms of both treatment cost reduction and environmental cost reduction. In contrast, for proposed scenarios with open dumping disposal or sanitary landfill with cover soil disposal selected for the final disposal process, those with incineration treatment facilities selected for the intermediate treatment process (scenarios 4, 6, 16 and 19) have relatively higher environmental efficiency. In summary, environmental efficiency of the waste disposal stream is not an index that is determined independently for each of the continuous steps of the system (i.e. collection, intermediate treatment and final disposal). It expresses comprehensive environmental economy of the waste disposal stream based on combinations of the process steps.

\section{Conclusions}

In this research, the LCA-EA model is applied to the current waste disposal stream of the BMR as well as other waste disposal streams assumed as scenarios, so that treatment cost, environmental load and environmental cost are assessed quantatively. The following outline the conclusions of this research:

(1) The current waste disposal stream in the BMR spends a great deal of its treatment cost budget on waste collection.

(2) Although proposed scenarios with incineration facilities selected have the highest $\mathrm{CO}_{2}$ 
emissions, for greenhouse effect gas emissions (total emissions of $\mathrm{CO}_{2}, \mathrm{CH}_{4}$ and $\mathrm{N}_{2} \mathrm{O}$ ), the baseline scenario is larger than the proposed scenarios.

(3) Although introduction of a proposed scenario means a cost increase because of an intermediate treatment process and final disposal process of the waste disposal stream, it can reduce environmental costs. Furthermore, because environmental cost occupies a large proportion of total cost, introduction of a proposed scenario is effective for reduction of total costs.

(4) Introduction of the proposed scenario to the current waste disposal stream (baseline scenario) of the BMR will improve environmental efficiency.

In this research, environmental impact that the waste disposal stream has regarding the waste released in the BMR in a single year can be assessed by the LCA-EA model. However, because waste treatment is performed over a long period of time, it is necessary to consider changes to environmental load as well as regions subject to environmental impact as time passes. Therefore, it is essential to perform LCA-EA model assessment over longer periods in order to study the environmental impact from the viewpoint of time.

\section{References}

1 Japan International Cooperation Agency (2005) Supporting Capacity Development in Solid Waste Management in Developing Countries -Towards Improving Solid Waste Management Capacity of Entire Societies. JICA-IFIC Study Report

2 Thailand Environment Institute (2006) Policy Study on Industrial Waste Management and Recycling. Thailand Environment Institute 
3 Pollution Control Department, Ministry of Natural Resources and Environment, Thailand (2005) Thailand State of Pollution Report 2005. Ministry of Natural Resources and Environment

4 Bartone CR (1999) Financing solid waste management projects in developing countries: Lessons from a decade of World Bank lending. Proceedings of the Organic Recovery and Biological Treatment 3:757-765

5 Sasaki S (2004) Current status and problems of solid wastes management in Bangkok; Application of regime-actor analysis (in Japanese). The Journal of Thai Studies 4:21-39

6 McDougall FR, White PR, Franke M, Hindle P (2001) Integrated Solid Waste Management: a Life Cycle Inventory (Second Edition). Blackwell Science

7 United States Environmental Protection Agency (1995) An Introduction to Environmental Accounting as a Business Management Tool: Key Concepts and Terms. United States Environmental Protection Agency

8 Clark RM (1978) Analysis of Urban Solid Waste Services -A Systems Approach-. Ann Arbor Science Publishers

9 Greenberg M, Caruana J, Krugman B (1976) Solid-waste management: a test of alternative strategies using optimization techniques. Environment and Planning 8:587597

10 Boustead I (1992) The relevance of re-use and recycling activities for the LCA profile of products. Proceedings of the 3rd CESIO International Surfactants Congress and Exhibition 218-226

11 Sushil (1990) Waste management: a systems perspective. Industrial Management and Data Systems 90/5:7-66 
12 Giljong OH, Matsuto T, Tanaka N. (1996) An analysis of factors influencing the collected quantities of household wastes and the construction of estimation models for those wastes (in Japanese). Journal of the Japan Society of Waste Management Experts 7/4:183-192

13 Matsuto T (2005) Toshi Gomi Shori Shisutemu no Bunseki Keikaku Hyouka (in Japanese). Gihodo Shuppan

14 Intergovernmental Panel on Climate Change (1997) Revised 1996 IPCC Guidelines for National Greenhouse Gas Inventories. NGGIP Publications

15 Moriizumi Y, Hondo $\mathrm{H}$ (2008) Estimation of $\mathrm{CO}_{2}$ intensities using an input-output table of Thailand (in Japanese). Journal of Japan Society of Energy and Resources 29/4:1-7

16 Shigetaka K, Shimakura Y, Goto T (2005) The transition of public project appraisal at Ministry of Land, Infrastructure and Transport Government of Japan (in Japanese). Proceedings of the 31th Annual Conference of Infrastructure Planning Division of JSCE 31:194 (in CD-ROM)

17 Tol RSJ (2005) The marginal damage costs of carbon dioxide emissions: an assessment of the uncertainties. Energy Policy 33:2064-2074

18 Hayashi Y (2005) Financial engineering cost estimation study for environmental contaminated site remediation (in Japanese). Proceedings of the 40th Japan National Conference on Geotechnical Engineering 2495-2496

19 Muttamara S, Leong ST (2004) The evolution of solid waste management in Bangkok. Thammasat International Journal of Science and Technology 9/1

20 Sasaki S (2006) Investigation of industrial waste management of Japanese industries in Thailand: in consideration of recyclable waste crossing the border. Proceedings of the International Conference on Hazardous Waste Management for a Sustainable Future 1012 
21 Ministry of the Environment, Japan (2008) Kyoto Protocol Target Achievement Plan (in Japanese). Ministry of the Environment

22 Itsubo N, Inaba A (2005) Evaluation Method of Environmental Impact through Lifecycle (in Japanese). Japan Environmental Management Association for Industry 


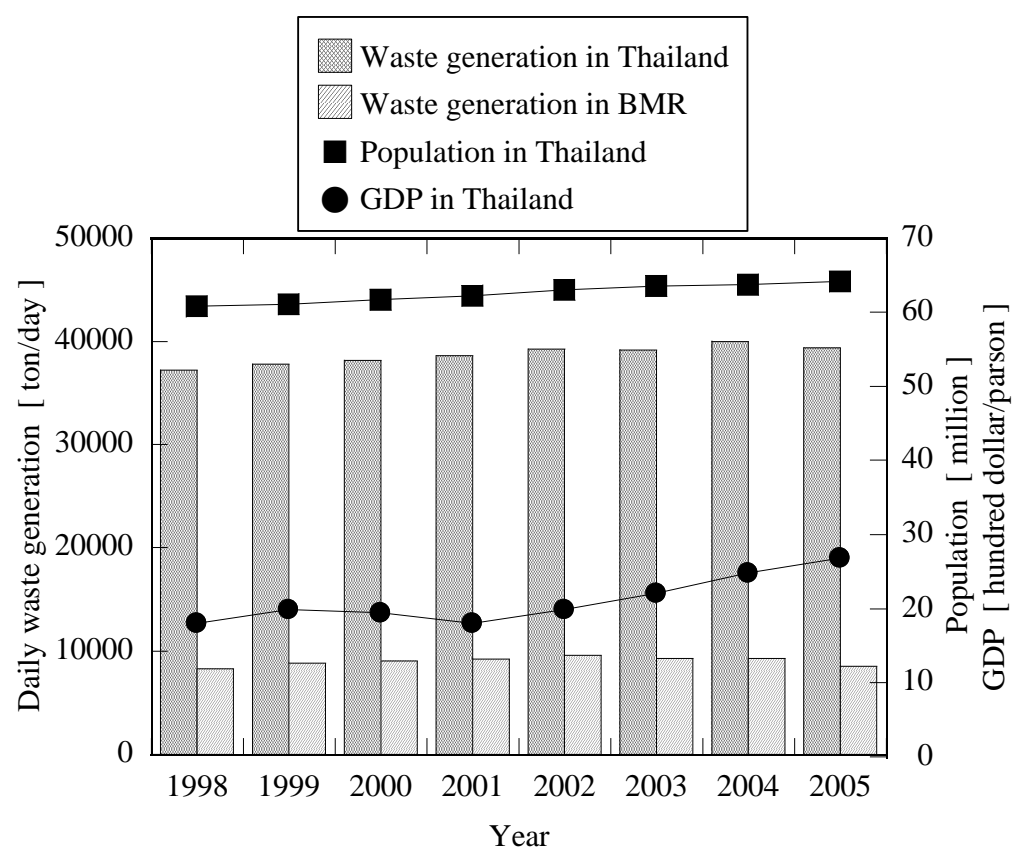

Figure 1 Waste generation, population, and GDP in the entire Thailand and the BMR.

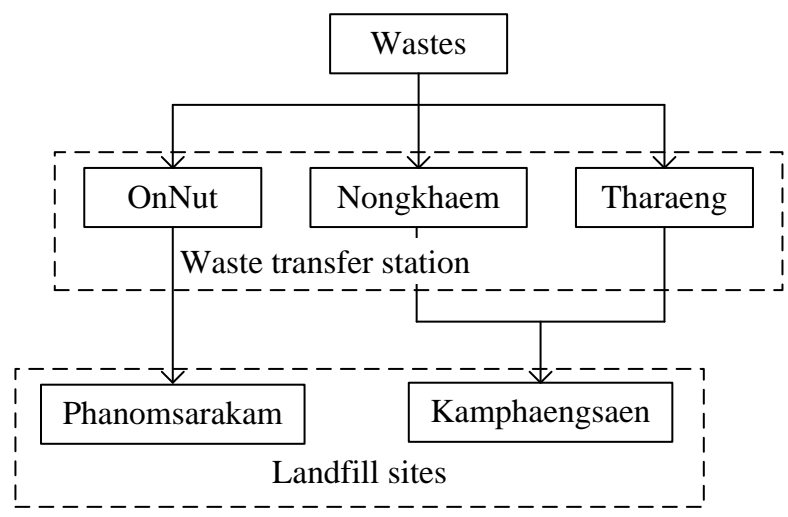

Figure 2 Flow of waste disposal stream in the BMR (from the waste transfer stations to the landfill sites) 


\begin{tabular}{|l|l|l|l|}
\hline Collection point \\
\hline Collection point
\end{tabular}

Figure 3 Various waste disposal processes applied to the waste disposal stream for the BMR

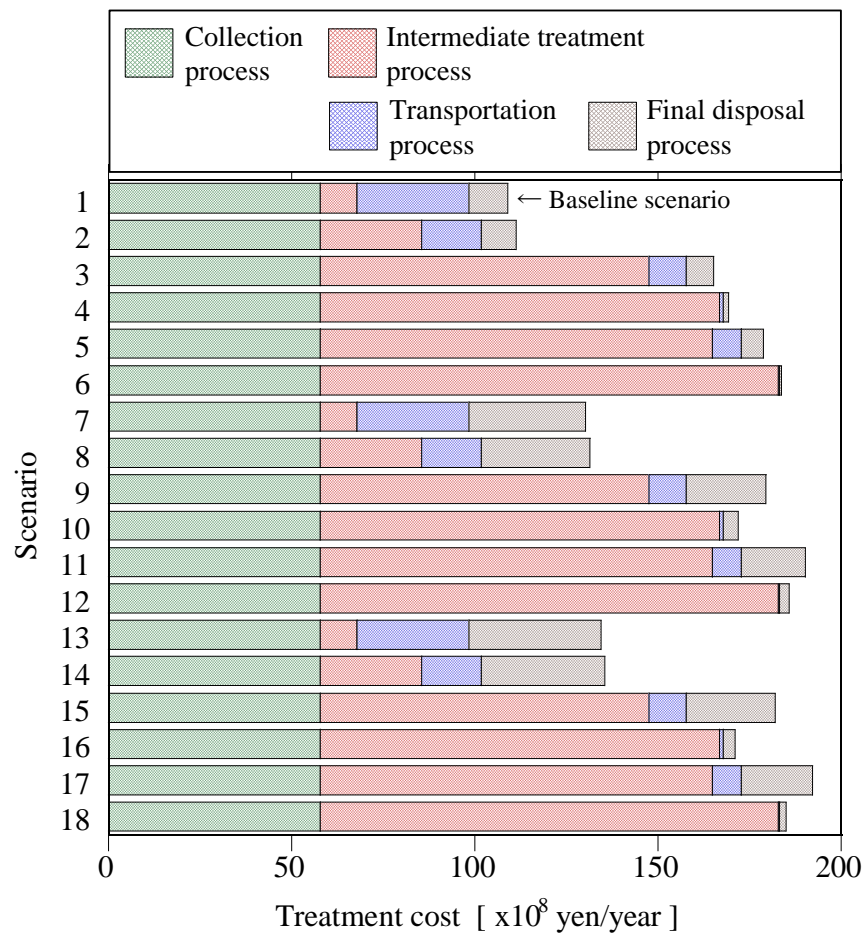

Figure 4 Estimated treatment costs of each proposed scenario 


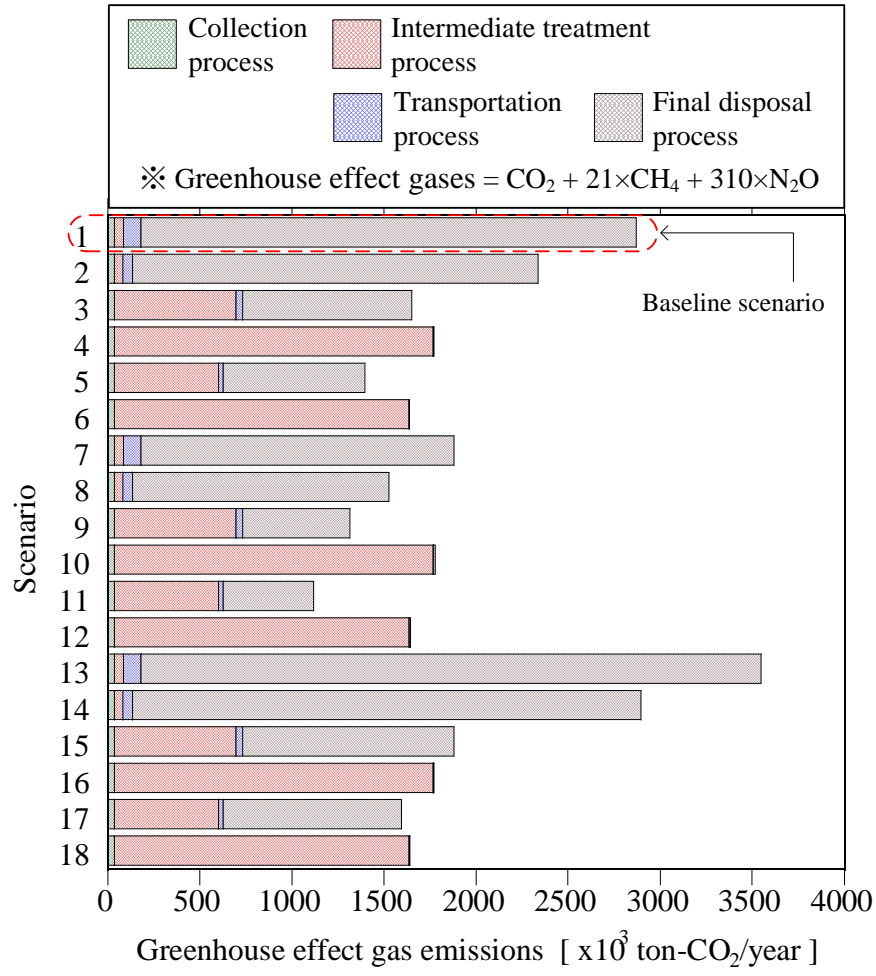

Figure 5 Estimated greenhouse effect gas emissions of each proposed scenario

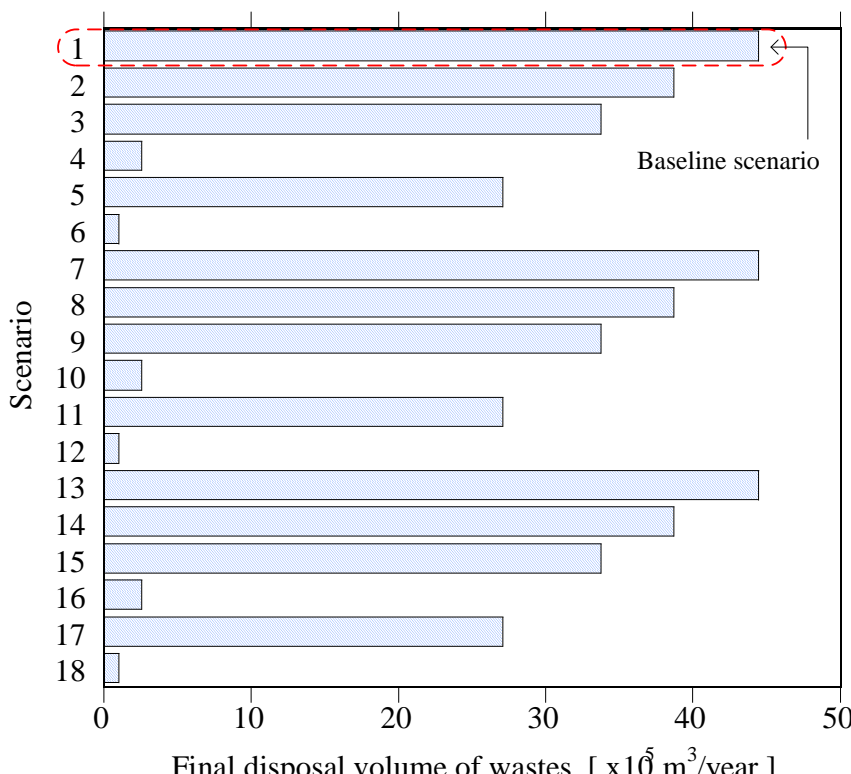

Figure 6 Estimated final disposal volume of wastes of each proposed scenario 


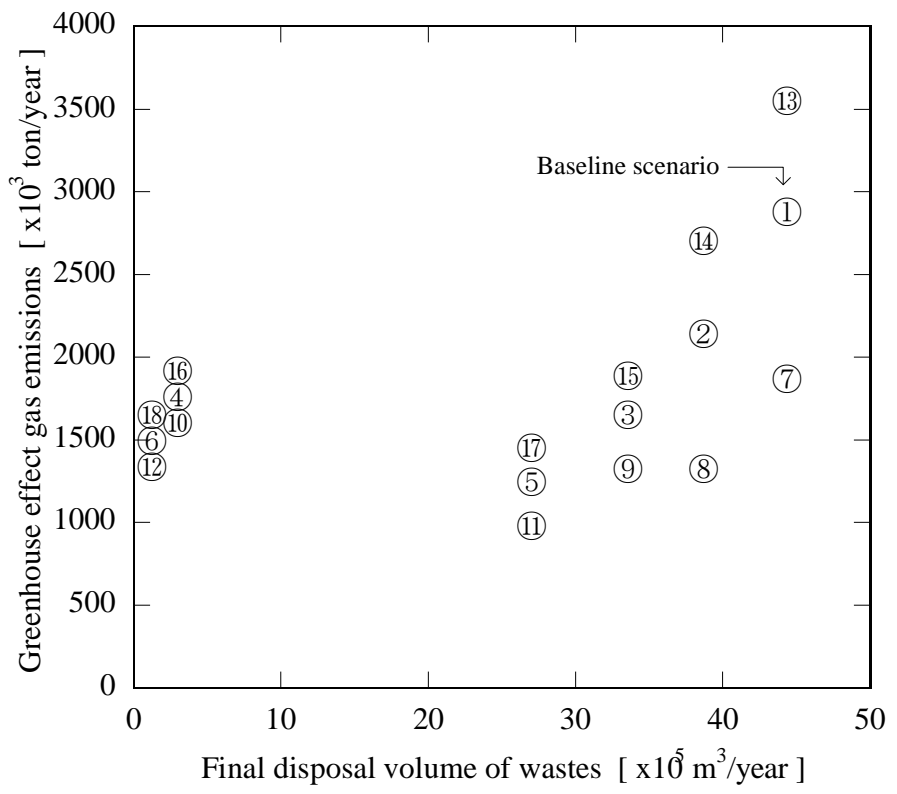

Figure 7 Relationship between greenhouse effect gas emissions and final disposal volume of waste for each proposed scenario

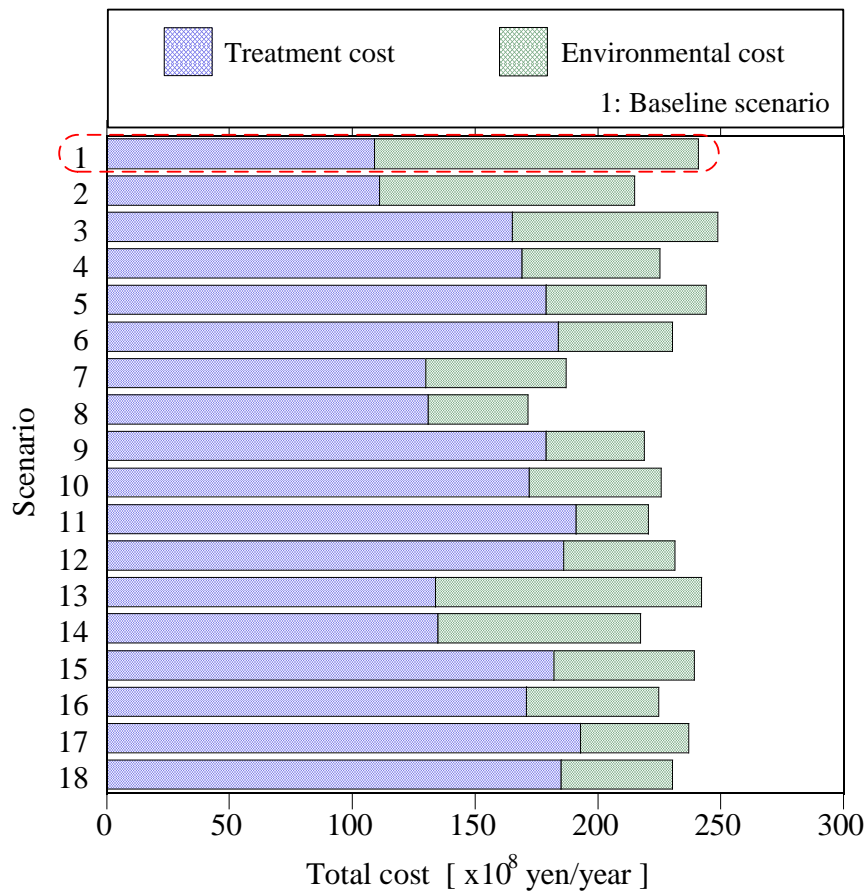

Figure 8 Estimated total cost of each proposed scenario 


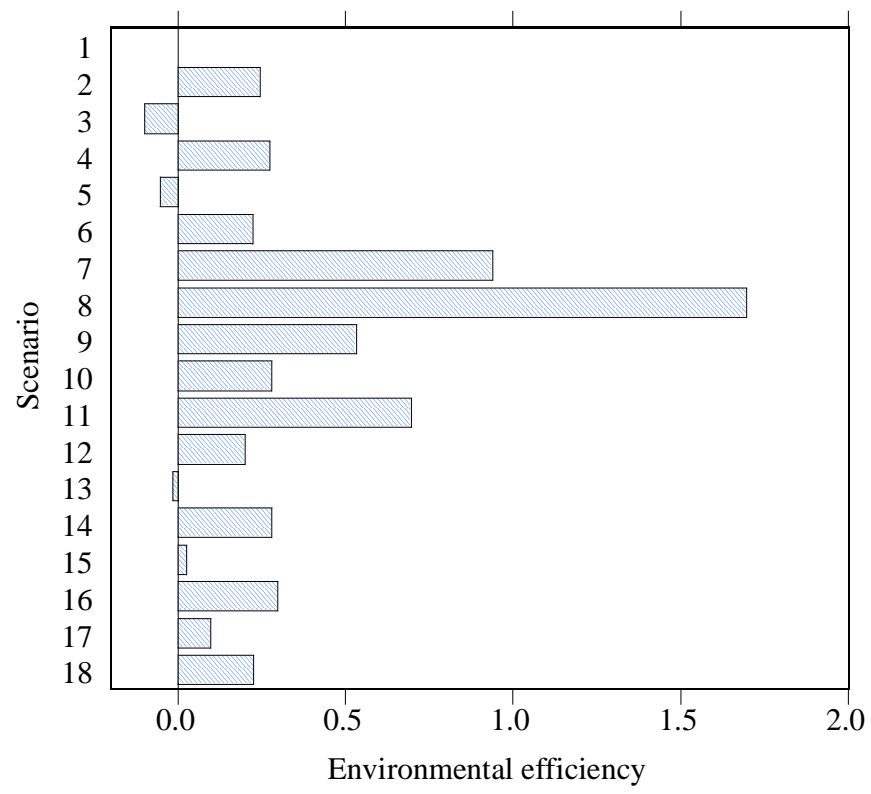

Figure 9 Environmental efficiency of each proposed scenario against the baseline scenario 
Table 1 Main contents of The Ninth National Economic \& Social Development Plan (2002) (Master Plan)

\begin{tabular}{|l|l|}
\hline \multicolumn{1}{|c|}{ Goal } & \multicolumn{1}{|c|}{ Guideline } \\
\hline $\begin{array}{l}\text { The generation of municipal } \\
\text { solid waste will be decreased to } \\
\text { less than 1.0kg/parson/day. }\end{array}$ & $\begin{array}{l}\text { An efficient system of the } \\
\text { municipal solid waste treatment } \\
\text { has to be established including } \\
\text { the collection, transportation, } \\
\text { intermediate treatment, and final } \\
\text { disposal. }\end{array}$ \\
\hline $\begin{array}{l}\text { The recycling rate for municipal } \\
\text { solid waste in Thailand will be } \\
\text { increased to more than 15\%. }\end{array}$ & $\begin{array}{l}\text { The generation of municipal } \\
\text { solid waste has to be controlled, } \\
\text { and recycling and reusing have } \\
\text { to be promoted. }\end{array}$ \\
\hline $\begin{array}{l}\text { All municipal solid wastes in } \\
\text { Bangkok area will be managed. }\end{array}$ & $\begin{array}{l}\text { The private-sector initiative to } \\
\text { operation of municipal solid } \\
\text { waste treatment system has to } \\
\text { be utilized. }\end{array}$ \\
\hline $\begin{array}{l}\text { The sanitary management of } \\
\text { municipal solid waste will be } \\
\text { surely executed, and appropriate } \\
\text { treatment system will be given. }\end{array}$ & $\begin{array}{l}\text { The participation of private } \\
\text { organization and citizens on the } \\
\text { municipal solid waste treatment } \\
\text { system has to be promoted. }\end{array}$ \\
\hline
\end{tabular}

Table 2 Regional population, waste generation and average distance to waste transfer station and landfill site, in the BMR

\begin{tabular}{|c|c|c|c|c|}
\hline Region & $\begin{array}{c}\text { Regional } \\
\text { population }\end{array}$ & $\begin{array}{c}\text { Waste } \\
\text { generation } \\
\text { (ton/day) }\end{array}$ & $\begin{array}{c}\text { Average distance from } \\
\text { each point to the solid } \\
\text { waste transfer station } \\
(\mathrm{km})\end{array}$ & $\begin{array}{c}\text { Average distance from } \\
\text { the solid waste transfer } \\
\text { station to the landfill site } \\
(\mathrm{km})\end{array}$ \\
\hline OnNut & $1,917,773$ & 2,700 & 16.8 & 92.7 \\
Nongkhaem & $2,583,824$ & 3,600 & 18.3 & 80.1 \\
Tharaeng & $1,151,902$ & 2,700 & 11.4 & 97.5 \\
\hline Total & $5,653,499$ & 9,000 & - & - \\
\hline
\end{tabular}

Table 3 Composition ratio to waste generation in the BMR

\begin{tabular}{|c|c|}
\hline Composition & Ratio $(\%)$ \\
\hline Food scraps & 35.89 \\
\hline Paper & 13.58 \\
\hline Cloth & 4.58 \\
\hline Plastic and foam & 20.76 \\
\hline Leather and rubber & 2.19 \\
\hline Wood and leaves & 6.59 \\
\hline Metal & 2.19 \\
\hline Glass & 5.07 \\
\hline Stones and ceramics & 0.58 \\
\hline Unclassifiable & 8.57 \\
\hline
\end{tabular}


Table 4 Emission factor and emission basic units of $\mathrm{CO}_{2}, \mathrm{CH}_{4}$, and $\mathrm{N}_{2} \mathrm{O}$ used in this research

(a) $\mathrm{CO}_{2}$

\begin{tabular}{|c|c|c|c|}
\hline Category & Sign & unit & $\begin{array}{c}\text { Emission factor } \\
\text { and emission } \\
\text { basic unit }\end{array}$ \\
\hline Electricity & $\overline{\theta_{1}}$ & $\left(\mathrm{~kg}-\mathrm{CO}_{2} / \mathrm{kWh}\right)$ & 0.69 \\
\hline Heavy fuel oil & $\theta_{2}$ & $\left(\mathrm{~kg}-\mathrm{CO}_{2} / \mathrm{L}\right)$ & 3.08 \\
\hline Light diesel oil & $\theta_{3}$ & $\left(\mathrm{~kg}-\mathrm{CO}_{2} / \mathrm{L}\right)$ & 2.70 \\
\hline $\begin{array}{l}\text { Civil engineering } \\
\text { work }\end{array}$ & $\theta_{4}$ & $\begin{array}{l}\left(\mathrm{kg}_{-}\right. \\
\left.\mathrm{CO}_{2} / 1,000 \text { yen }\right)\end{array}$ & 1.91 \\
\hline Building work & $\theta_{5}$ & $\begin{array}{l}\left(\mathrm{kg}_{-}\right. \\
\left.\mathrm{CO}_{2} / 1,000 \mathrm{yen}\right)\end{array}$ & 0.96 \\
\hline $\begin{array}{l}\text { Maintenance and } \\
\text { repair }\end{array}$ & $\theta_{6}$ & $\begin{array}{l}\left(\mathrm{kg}^{-}\right. \\
\left.\mathrm{CO}_{2} / 1,000 \mathrm{yen}\right)\end{array}$ & 1.16 \\
\hline Heavy machinery & $\theta_{7}$ & $\begin{array}{l}\left(\mathrm{kg}_{-}\right. \\
\left.\mathrm{CO}_{2} / 1,000 \mathrm{yen}\right)\end{array}$ & 0.97 \\
\hline Collection vehicle & $\theta_{8}$ & $\begin{array}{l}(\mathrm{kg}- \\
\left.\mathrm{CO}_{2} / 1,000 \text { yen }\right)\end{array}$ & 0.97 \\
\hline Haulage vehicle & $\theta_{9}$ & $\begin{array}{l}\left(\mathrm{kg}_{-}\right. \\
\left.\mathrm{CO}_{2} / 1,000 \text { yen }\right)\end{array}$ & 0.97 \\
\hline Hydrated lime & $\theta_{10}$ & $\left(\mathrm{~kg}-\mathrm{CO}_{2} / \mathrm{ton}\right)$ & 1,096 \\
\hline $\begin{array}{l}\text { Water treatment } \\
\text { chemicals }\end{array}$ & $\theta_{11}$ & $\left(\mathrm{~kg}-\mathrm{CO}_{2} / \mathrm{m}^{3}\right)$ & 0.11 \\
\hline
\end{tabular}

(b) $\mathrm{CH}_{4}$

\begin{tabular}{|c|c|c|c|}
\hline Category & Sign & unit & $\begin{array}{l}\text { Emission factor } \\
\text { and emission } \\
\text { basic unit }\end{array}$ \\
\hline \multicolumn{4}{|c|}{ Compost treatment } \\
\hline Food & $\sigma_{C H 4}$ & $\left(\mathrm{~kg}-\mathrm{CH}_{4} / \mathrm{ton}\right)$ & 4 \\
\hline Paper & $\sigma_{C H A}{ }_{C P}$ & $\left(\mathrm{~kg} \mathrm{CH}_{4} / \mathrm{ton}\right)$ & 10 \\
\hline Cloth & $\sigma_{C H 4 C C}$ & $\left(\mathrm{~kg}-\mathrm{CH}_{4} / \mathrm{ton}\right)$ & 10 \\
\hline Wood & $\sigma_{C H 4 C W}$ & 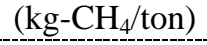 & 10 \\
\hline \multicolumn{4}{|l|}{ Final disposal } \\
\hline Food & $\sigma_{C H 4 F F}$ & $\left(\mathrm{~kg}-\mathrm{CH}_{4} / \mathrm{ton}\right)$ & 0.223 \\
\hline Paper & $\sigma_{C H 4 F P}$ & $\left(\mathrm{~kg}-\mathrm{CH}_{4} / \mathrm{ton}\right)$ & 0.210 \\
\hline Cloth & $\sigma_{C H 4 F C}$ & $\left(\mathrm{~kg}-\mathrm{CH}_{4} / \mathrm{ton}\right)$ & 0.232 \\
\hline Wood & $\sigma_{\mathrm{CH}_{4} F_{-} W}$ & $\left(\mathrm{~kg}-\mathrm{CH}_{4} / \mathrm{ton}\right)$ & 0.231 \\
\hline
\end{tabular}

(c) $\mathrm{N}_{2} \mathrm{O}$

\begin{tabular}{|c|c|c|c|}
\hline Category & Sign & unit & $\begin{array}{c}\text { Emission factor } \\
\text { and emission } \\
\text { basic unit }\end{array}$ \\
\hline \multicolumn{4}{|c|}{ Compost treatment } \\
\hline Food & $\sigma_{N 2 O \quad C F}$ & $\left(\mathrm{~kg}-\mathrm{N}_{2} \mathrm{O} / \mathrm{ton}\right)$ & 0.3 \\
\hline Paper & $\sigma_{N 2 O \quad C P}$ & $\left(\mathrm{~kg}-\mathrm{N}_{2} \mathrm{O} / \mathrm{ton}\right)$ & 0.6 \\
\hline Cloth & $\sigma_{N 2 O C C}$ & $\left(\mathrm{~kg}-\mathrm{N}_{2} \mathrm{O} / \mathrm{ton}\right)$ & 0.6 \\
\hline Wood & $\sigma_{N 2 O C W}$ & $\left(\mathrm{~kg}-\mathrm{N}_{2} \mathrm{O} / \mathrm{ton}\right)$ & 0.6 \\
\hline
\end{tabular}


Table 5 Assumed basic unit of each price including selling price for the BMR

(a) Basic unit

\begin{tabular}{|l|c|c|c|}
\hline \multicolumn{1}{|c|}{ Category } & Sign & Unit & $\begin{array}{c}\text { Monetary value } \\
\text { basic unit }\end{array}$ \\
\hline Employment cost & $\psi_{0}$ & (yen/parson) & 720,000 \\
\hline Electricity & $\psi_{1}$ & (yen/kWh) & 9 \\
\hline Heavy fuel oil & $\psi_{2}$ & (yen/L) & 18 \\
\hline Light diesel oil & $\psi_{3}$ & (yen/L) & 30 \\
\hline Heavy machinery & $\psi_{7}$ & (yen/vehicle) & $10,666,667$ \\
\hline $\begin{array}{l}\text { Collection } \\
\text { vehicle }\end{array}$ & $\psi_{8}$ & (yen/vehicle) & $1,666,667$ \\
\hline Haulage vehicle & $\psi_{9}$ & $($ yen/vehicle) & $3,333,333$ \\
\hline Hydrated lime & $\psi_{10}$ & $($ yen/ton) & 6,667 \\
\hline $\begin{array}{l}\text { Water treatment } \\
\text { chemicals }\end{array}$ & $\psi_{11}$ & $\left(\right.$ yen/m $\left./ \mathrm{m}^{3}\right)$ & 6 \\
\hline
\end{tabular}

(b) Selling basic unit

\begin{tabular}{|l|c|l|c|}
\hline \multicolumn{1}{|c|}{ Category } & Sign & Unit & $\begin{array}{c}\text { Selling monetary value } \\
\text { basic unit }\end{array}$ \\
\hline Paper & $\Phi_{1}$ & (yen/ton) & 28 \\
\hline Plastic & $\Phi_{2}$ & (yen/ton) & 1,019 \\
\hline Glass & $\Phi_{3}$ & (yen/ton) & 155 \\
\hline Steel & $\Phi_{4}$ & (yen/ton) & 1,125 \\
\hline
\end{tabular}


Table 6 Assumed several scenarios of waste disposal stream for the BMR

\begin{tabular}{|c|c|c|c|c|}
\hline & Collection & Intermediate treatment & Transportation & Final disposal \\
\hline 1 & \multirow{18}{*}{ Identification } & No treatment & \multirow{18}{*}{ Identification } & \multirow{6}{*}{ Open dumping } \\
\hline 2 & & Resource sorting & & \\
\hline 3 & & Compost treatment & & \\
\hline 4 & & Incineration treatment & & \\
\hline 5 & & $\begin{array}{l}\text { Resource sorting }+ \\
\text { Compost treatment }\end{array}$ & & \\
\hline 6 & & $\begin{array}{l}\text { Resource sorting }+ \\
\text { Incineration treatment }\end{array}$ & & \\
\hline 7 & & No treatment & & \multirow{6}{*}{$\begin{array}{l}\text { Sanitary landfill } \\
\text { without cover soil }\end{array}$} \\
\hline 8 & & Resource sorting & & \\
\hline 9 & & Compost treatment & & \\
\hline 10 & & Incineration treatment & & \\
\hline 11 & & $\begin{array}{l}\text { Resource sorting }+ \\
\text { Compost treatment }\end{array}$ & & \\
\hline 12 & & $\begin{array}{l}\text { Resource sorting }+ \\
\text { Incineration treatment }\end{array}$ & & \\
\hline 13 & & No treatment & & \multirow{6}{*}{$\begin{array}{l}\text { Sanitary landfill with } \\
\text { cover soil }\end{array}$} \\
\hline 14 & & Resource sorting & & \\
\hline 15 & & Compost treatment & & \\
\hline 16 & & Incineration treatment & & \\
\hline 17 & & $\begin{array}{l}\text { Resource sorting }+ \\
\text { Compost treatment }\end{array}$ & & \\
\hline 18 & & $\begin{array}{l}\text { Resource sorting + } \\
\text { Incineration treatment }\end{array}$ & & \\
\hline
\end{tabular}

